\title{
Osteopathic Manipulative Treatment for Infants in the NICU:A Systematic Review
}

\section{Hunter J Wernick ${ }^{1}$ and Murray R Berkowitz ${ }^{2 *}$}

${ }^{1}$ Adolescent Medicine, Department of Pediatrics, Nationwide Children's Hospital, Columbus, Ohio, USA

${ }^{2}$ Department of Osteopathic Manipulative Medicine, Philadelphia College of Osteopathic Medicine - Georgia Campus, Suwanee, Georgia, USA

*Corresponding Author: Murray R Berkowitz, Professor, Neuromusculoskeletal Medicine and Osteopathic Manipulative Medicine, Philadelphia College of Osteopathic Medicine - Georgia Campus Old Peachtree Road NW, Suwanee, Georgia, USA.

Received: September 04, 2019; Published: September 09, 2019

DOI: 10.31080/ASMS.2019.03.0404

\begin{abstract}
Objectives: The aim of this systematic review is to critically evaluate the use and effectiveness of osteopathic manipulative treatment (OMT) as an adjunct treatment option for infants in the neonatal intensive care unit (NICU).

Methods: A systematic literature search was conducted through February 2016 using three databases (PubMed, Scopus, and Embase). The search was performed for any type of clinical study using OMT on infants in the NICU. Case reports, cohort studies, randomized controlled trials and basic research were included. There were no date limitations for these searches.

Results: Ten titles met the criteria for this review. Results suggest a potential positive effect of osteopathic manipulation on infants admitted to the NICU in terms of decreased LOS and cost benefits. Only one study showed negative effects.

Conclusion: Clinically relevant effects of OMT were found for reducing LOS and cost as well as improving functional status in infants admitted to the NICU. Only one study found OMT to cause a longer LOS.
\end{abstract}

Keywords: Osteopathic Manipulative; NICU; Medicine

\section{Introduction}

Advances in medicine have allowed for the care and treatment of premature infants who previously would not have survived. Neonatal Intensive Care Units (NICUs) specialize in the care of newborns with complex medical conditions, such as prematurity which is associated with low birth weight and respiratory distress. Preterm birth is a rising concern worldwide and is a public health interest, with about 15 million premature births around the world [1]. There has been a reduction in preterm birth rate by approximately $8 \%$ from 2007 (10.44\% to 9.75\%) [2]. This is most likely due to the increased awareness of the risks of early deliveries and the use of the NICU. The definition of preterm birth is a live birth before 37 weeks of gestational age (GA). By comparison a full term birth is $\geq 39$ weeks GA. There are sub - categories of preterm birth: extremely preterm $<28$ weeks GA $(10 \%)$, very preterm $<32$ weeks
GA (10\%), moderate to late preterm < 37 weeks GA (> 80\%) [3]. Placement of premature infants in the neonatal intensive care unit (NICU) is costly and still does not guarantee survival. In 2005, it was estimated that the annual societal economic price related to preterm birth in the United States was at least $\$ 26.2$ billion, taking into account medical, educational and lost productivity costs. Length of hospital stay correlates with gestational age and is linked to the cost of medical care. The average length of stay (LOS) for a preterm infant is about 13 days which is much greater than 1.5 days for a term baby [4]. The average hospital cost for the first year of life for a preterm or low birth weight infant is estimated to be $\$ 54,194$ compared to an uncomplicated healthy newborn which costs about $\$ 4,389$ [5]. There are four broad categories that allow the newborn to leave the NICU, these consist of: adequate control of breathing, successful breathing without need for supplemental 
oxygen, adequate oral feeding, and maintenance of body temperature without the provision of supplemental heat [6]. The hypoglossal nerve or glossopharyngeal nerve can become entrapped within the foramen as they exit the cranium and can be associated with abnormal suck and swallowing functions [7]. Osteopathic Manipulative Treatment (OMT) is an adjunct to routine medical care that is used by osteopathic physicians. OMT to the cranial somatic dysfunctions may improve suckling and swallowing in these infants. In 2005, Guiney and associates published a randomized controlled trial where OMT was performed on pediatric patients with asthma. The results showed improved pulmonary function measured by objective pulmonary function testing [8].

In 2013, Posadzki and associates [9] wrote a systematic review on the use of OMT for different pediatric conditions. The Posadzki review included only randomized controlled trials and limited information about OMT use in the NICU. Subsequent studies have been released since the Posadzki systematic review, and it is these more recent works that are the focus of this study. The aim of this systematic review is to examine all of the evidence of using osteopathic medicine for diagnosis and to evaluate the effectiveness of OMT as a treatment option for infants in the NICU.

\section{Methods}

Identification of studies

A systematic literature search was conducted on each of the following databases from December 2015 to March 2016: PUBMED, SCOPUS, EMBASE. Each search included the following key words: "osteopathic manipulation" OR "osteopathic manipulative treatment" OR "osteopathic manipulative therapy" OR "osteopathic manual therapy" AND "preterm infant" OR "preterm" OR "premature infant" OR "NICU" OR "neonate" OR "neonatology". Abstracts and titles were evaluated for duplicates and relevance.

\section{Study selection}

The inclusion criteria for this systematic review are infants in the NICU for any disease who received osteopathic manipulative treatment, as well as infants who received an osteopathic examination. Case reports, cohort studies, observational studies, and randomized controlled trials were included. There were no date limitations for these searches. Studies were excluded if they were not relevant to infants in the NICU (eg, if study's title indicated that the study was about neonates or infants but these children were not in the NICU), if infants in the NICU were not receiving an osteopathic evaluation and/or treatment, if the study included chiropractic manipulation or physiotherapy, and if the study was not in English.

The study selection process consisted of 2 steps. During the first step, the articles' title and abstracts were reviewed. The studies that did not meet the inclusion criteria within the title and abstracts were excluded during this stage. Duplicate citations found in multiple databases were also excluded in the first step. Full - text versions of the remaining articles were obtained and the eligibility criterion was applied to the full - text of the articles. The schematic of the article selection is shown in figure 1 .

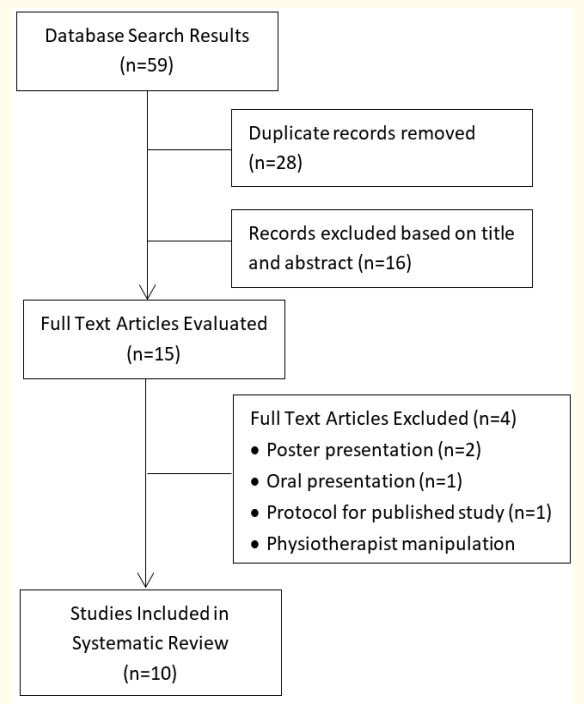

Figure 1: Flow Diagram of Study Selection.

\section{Data extraction}

The following information was extracted from the included studies: first author and year of publication, objective of the study, characteristics of participants, methods (including what type of study, control and study groups), experimental intervention, outcome measures, results, and limitations. table 1 has a summary of all the articles presented in this systematic review. LOS and cost analysis was also extracted from three studies and is shown in table 2. 


\begin{tabular}{|c|c|c|c|c|c|c|c|c|c|}
\hline Reference & $\begin{array}{l}\text { Study } \\
\text { Design }\end{array}$ & Objective & $\begin{array}{c}\text { Patient } \\
\text { Population }\end{array}$ & Groups & $\mathbf{n}$ & $\begin{array}{c}\text { Frequency and } \\
\text { Duration of } \\
\text { Treatment } \\
\text { Sessions }\end{array}$ & Intervention & $\begin{array}{l}\text { Outcome } \\
\text { Measures }\end{array}$ & Results \\
\hline $\begin{array}{l}\text { Lund., et } \\
\text { al. } 2011^{[13]}\end{array}$ & Case Study & $\begin{array}{l}\text { Add to the interest } \\
\text { and support for } \\
\text { a clinical trial of } \\
\text { OMT and its effect } \\
\text { on poor nipple } \\
\text { feeding in devel- } \\
\text { oping premature } \\
\text { newborns and } \\
\text { infants }\end{array}$ & $\begin{array}{l}\text { Premature } \\
\text { twin girls } \\
\text { born at } 24 \\
6 / 7 \text { weeks } \\
\text { GA }\end{array}$ & Experimental & 2 & Daily for 3 weeks & $\begin{array}{l}\text { ST, BLT, MR, } \\
\text { inhibition, } \\
\text { cranial oste- } \\
\text { opathy }\end{array}$ & $\begin{array}{l}\text { 1.\# total feeds } \\
2 . \# \text { nipple } \\
\text { feeds } \\
\text { 3.volume of } \\
\text { fluid taken for } \\
\text { each feed } \\
\text { 4.feed type }\end{array}$ & $\begin{array}{l}\text { Both twins' nip- } \\
\text { ple feeding skills } \\
\text { progressed to } \\
\text { full oral feeding } \\
\text { within } 3 \text { weeks of } \\
\text { OMT. }\end{array}$ \\
\hline $\begin{array}{l}\text { Pizzolo- } \\
\text { russo., et } \\
\text { al. } 2011^{[15]}\end{array}$ & $\begin{array}{l}\text { Prospec- } \\
\text { tive Cohort } \\
\text { Study }\end{array}$ & $\begin{array}{l}\text { Effect of OMT on GI } \\
\text { function and LOS } \\
\text { of preterm infants }\end{array}$ & $\begin{array}{l}\text { Premature } \\
\text { infants in } \\
\text { NICU >29 } \\
\text { and <37 } \\
\text { weeks GA }\end{array}$ & $\begin{array}{l}\text { Control } \\
\text { Experimental }\end{array}$ & $\begin{array}{l}188 \\
162\end{array}$ & $\begin{array}{l}2 \mathrm{x} / \mathrm{wk} \text { for } 20-30 \\
\min \end{array}$ & $\begin{array}{l}\text { Indirect myo- } \\
\text { fascial, sutural } \\
\text { spread, BLT, } \\
\text { BMT }\end{array}$ & $\begin{array}{l}\text { 1.LOS } \\
\text { 2.GI sxs }\end{array}$ & $\begin{array}{l}1 . \mathrm{OR}=0.22 \\
2 . \mathrm{OR}=0.45\end{array}$ \\
\hline $\begin{array}{l}\text { Pizzolo- } \\
\text { russo., et } \\
\text { al. } 2013^{[14]}\end{array}$ & $\begin{array}{l}\text { Retro- } \\
\text { spective } \\
\text { Review }\end{array}$ & $\begin{array}{l}\text { Determine preva- } \\
\text { lence of SD and } \\
\text { cranial strain pat- } \\
\text { tern in newborns } \\
\text { at the first osteo- } \\
\text { pathic structural } \\
\text { exam }\end{array}$ & $\begin{array}{l}\text { Preterm } \\
\text { and term } \\
\text { newborns } \\
\text { admitted to } \\
\text { NICU }\end{array}$ & Experimental & 155 & Once & $\begin{array}{l}\text { OE only - } \\
\text { lying supine } \\
\text { or prone in an } \\
\text { open crib or } \\
\text { incubator }\end{array}$ & $\mathrm{N} / \mathrm{A}$ & $\begin{array}{l}\text { SD of pelvis and } \\
\text { spine occurred } \\
\text { frequently. } \\
\text { Most frequent } \\
\text { cranial SD were } \\
\text { SBS compression } \\
\text { and lateral-verti- } \\
\text { cal strain pattern } \\
\end{array}$ \\
\hline $\begin{array}{l}\text { Cerritelli., } \\
\text { et al. } 2013 \\
{[16]}\end{array}$ & RCT & $\begin{array}{l}\text { Investigate the } \\
\text { effect of OMT on } \\
\text { LOS in premature } \\
\text { infants }\end{array}$ & $\begin{array}{l}\text { Preterm } \\
\text { infants }>28 \\
\text { and }<38 \\
\text { weeks GA }\end{array}$ & $\begin{array}{l}\text { Control } \\
\text { Experimental }\end{array}$ & 54 & $\begin{array}{l}2 x / \text { wk for } 20 \\
\min \\
2 x / \text { wk for } 20 \\
\min \end{array}$ & $\begin{array}{l}\text { OE then no } \\
\text { touch } \\
\text { MR, BLT, BMT, } \\
\text { indirect fluidic } \\
\text { and v-spread }\end{array}$ & $\begin{array}{l}\text { 1.LOS } \\
\text { 2.DWG } \\
\text { 3.Cost }\end{array}$ & $\begin{array}{l}\text { 1.Sig }(6 d, \\
p<0.001) \\
\text { 2.NS } \\
\text { 3.Sig }(\$ 3,229.82 ; \\
p=0.01)\end{array}$ \\
\hline $\begin{array}{l}\text { Pizzolo- } \\
\text { russo., et } \\
\text { al. } 2014^{[17]}\end{array}$ & RCT & $\begin{array}{l}\text { Assess if osteo- } \\
\text { pathic care is ef- } \\
\text { fective in reducing } \\
\text { LOS and that early } \\
\text { OMT produces the } \\
\text { most pronounced } \\
\text { benefit, compared } \\
\text { to moderately } \\
\text { early and late OMT. }\end{array}$ & $\begin{array}{l}\text { MP and LP } \\
\text { infants in } \\
\text { NICU 32-37 } \\
\text { weeks GA }\end{array}$ & $\begin{array}{l}\text { Control } \\
\text { Experimental }\end{array}$ & $\begin{array}{l}55 \\
55\end{array}$ & $\begin{array}{l}2 x / \text { wk for } 20 \\
\min \\
2 x / \text { wk for } 20 \\
\min \end{array}$ & $\begin{array}{l}\text { OE then no } \\
\text { touch } \\
\text { Indirect myo- } \\
\text { fascial release, } \\
\text { BLT, BMT }\end{array}$ & $\begin{array}{l}\text { 1.LOS } \\
\text { 2.Cost }\end{array}$ & $\begin{array}{l}\text { 1.Sig Early (4d; } \\
\text { p<0.001) } \\
\text { Mod Early (3d; } \\
\text { P<0.001) } \\
\text { Late (2d; }<<0.01) \\
2 . \operatorname{Sig}(\$ 812.19 ; \\
\text { p-0.001) }\end{array}$ \\
\hline $\begin{array}{l}\text { Martelli., } \\
\text { et al. } 2014 \\
\text { [19] }\end{array}$ & RCT & $\begin{array}{l}\text { To assess the pres- } \\
\text { ence of placebo ef- } \\
\text { fect in newborns } \\
\text { using sham OMT }\end{array}$ & $\begin{array}{l}\text { Preterm } \\
\text { infants in } \\
\text { NICU 29-36 } \\
\text { weeks GA }\end{array}$ & $\begin{array}{l}\text { Control } \\
\text { Sham }\end{array}$ & $\begin{array}{l}103 \\
103\end{array}$ & $\begin{array}{l}2 \mathrm{x} / \mathrm{wk} \text { for } 20 \mathrm{~min} \\
2 \mathrm{x} / \mathrm{wk} \text { for } 20 \mathrm{~min}\end{array}$ & $\begin{array}{l}\text { No touch, laid } \\
\text { quietly } \\
\text { OE + light } \\
\text { touch through } \\
\text { entire MSK } \\
\text { system }\end{array}$ & $\begin{array}{l}\text { 1.LOS } \\
\text { 2.DWG }\end{array}$ & $\begin{array}{l}\text { 1.NS }(p=0.70) \\
\text { 2.NS }(p=0.74)\end{array}$ \\
\hline $\begin{array}{l}\text { Cerritelli., } \\
\text { et al. } 2014\end{array}$ & Model & $\begin{array}{l}\text { Suggest a stan- } \\
\text { dardized approach } \\
\text { on osteopathic } \\
\text { approach (NE-O } \\
\text { model) in treat- } \\
\text { ing hospitalized } \\
\text { newborns. }\end{array}$ & $\begin{array}{l}\text { Preterm } \\
\text { and term } \\
\text { newborns in } \\
\text { NICU }\end{array}$ & Experimental & 100 & $30 \mathrm{~min}$ & $\begin{array}{l}\text { Counterstrain, } \\
\text { cranial facili- } \\
\text { tated position- } \\
\text { al release, } \\
\text { functional, BLT }\end{array}$ & $\mathrm{N} / \mathrm{A}$ & $\begin{array}{l}\text { Showed the } \\
\text { effectiveness of } \\
\text { this osteopathic } \\
\text { model in reduc- } \\
\text { ing preterms' LOS } \\
\text { and hospital costs }\end{array}$ \\
\hline
\end{tabular}




\begin{tabular}{|c|c|c|c|c|c|c|c|c|c|}
\hline $\begin{array}{l}\text { Cerritelli., } \\
\text { et al. } \\
2015^{18}\end{array}$ & RCT & $\begin{array}{l}\text { Study the extent to } \\
\text { which OMT is ef- } \\
\text { fective in reducing } \\
\text { LOS in a sample of } \\
\text { premature infants } \\
\text { at } 3 \text { NICUs }\end{array}$ & $\begin{array}{l}\text { Preterm } \\
\text { newborns } \\
\text { 29-37 weeks } \\
\text { GA }\end{array}$ & $\begin{array}{l}\text { Control } \\
\text { Experimental }\end{array}$ & $\begin{array}{l}343 \\
352\end{array}$ & $\begin{array}{l}2 x / \text { wk for } 30 \\
\min \\
2 x / \text { wk for } 30 \\
\min \end{array}$ & $\begin{array}{l}\text { OE then no } \\
\text { touch } \\
\text { MR, BLT, BMT }\end{array}$ & $\begin{array}{l}\text { 1.LOS } \\
\text { 2.DWG } \\
\text { 3.Cost }\end{array}$ & $\begin{array}{l}1 . S i g \\
(4 d ; p<0.001) \\
\text { 2.NS }(p=0.35) \\
3 . \operatorname{Sig}(\$ 1,731.53 ; \\
p<0.001)\end{array}$ \\
\hline $\begin{array}{l}\text { Haiden., et } \\
\text { al. } 2015\end{array}$ & RCT & $\begin{array}{l}\text { Determine if } \\
\text { visceral OMT ac- } \\
\text { celerates complete } \\
\text { meconium excre- } \\
\text { tion and improved } \\
\text { feeding tolerance } \\
\text { in very low birth } \\
\text { weight infants }\end{array}$ & $\begin{array}{l}\text { Premature } \\
\text { infants with } \\
\text { birth weight } \\
<1500 \text { and } \\
\text { GA }<32 \\
\text { weeks }\end{array}$ & $\begin{array}{l}\text { Control } \\
\text { Experimental }\end{array}$ & $\begin{array}{l}20 \\
21\end{array}$ & $\begin{array}{l}3 \text { days during } 1^{\text {st }} \\
\text { week of life }\end{array}$ & $\begin{array}{l}\text { None } \\
\text { Series of } 9 \\
\text { visceral treat- } \\
\text { ments adapted } \\
\text { from protocol } \\
\text { for adults }\end{array}$ & 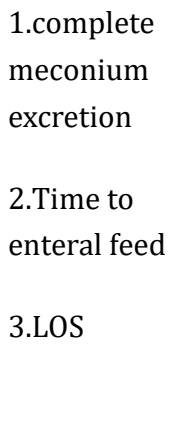 & $\begin{array}{l}\begin{array}{l}1 . S i g \\
\text { ger; } p=0.16 \mathrm{~d} \text { lon- }\end{array} \\
\begin{array}{l}2 . \operatorname{Sig}(7 \mathrm{~d} \text { longer; } \\
\mathrm{p}=0.2)\end{array} \\
\begin{array}{l}3 . \operatorname{Sig}(34 \mathrm{~d} \text { longer; } \\
\mathrm{p}=0.14)\end{array}\end{array}$ \\
\hline $\begin{array}{l}\text { Cerritelli., } \\
\text { et al. } 2015\end{array}$ & $\begin{array}{l}\text { RCT Pro- } \\
\text { tocol }\end{array}$ & $\begin{array}{l}\text { Explore the ef- } \\
\text { fectiveness of OMT } \\
\text { in reducing pain } \\
\text { in a sample of pre- } \\
\text { terms in NICU }\end{array}$ & $\begin{array}{l}\text { Preterm } \\
\text { newborns }\end{array}$ & $\begin{array}{l}\text { Control } \\
\text { Experimental } \\
\text { Sham }\end{array}$ & $\begin{array}{l}40 \\
40 \\
40\end{array}$ & $\begin{array}{l}\text { None } \\
1 \mathrm{x} / \text { wk for } 30 \\
\min \\
1 \mathrm{x} / \text { wk for } 30 \\
\min \end{array}$ & $\begin{array}{l}\text { None, RC only } \\
\text { BLT, BMT } \\
\text { 'soft touch' }\end{array}$ & $\begin{array}{l}\text { 1.PIPP Q } \\
\text { 2.LOS } \\
\text { 3.Cost }\end{array}$ & $\mathrm{N} / \mathrm{A}$ \\
\hline
\end{tabular}

Table 1: Description of all the studies included in this review.

AE: Adverse Events; BLT: Balanced Ligamentous Tension; BMT: Balanced Membranous Tension; CG: Control Group; DWG: Daily Weight Gain; GA: Gestational Age; GI: Gastrointestinal; GT: Gastrostomy Tube; LOS: Length Of Stay; LP: Late Preterm; LS: Lumbosacral; MP: Moderate Preterm; MR: Myofascial Release; MSK: Musculoskeletal; N/A: Not Applicable; NICU: Neonatal Intensive Care Unit; OE: Osteopathic Evaluation; OMM: Osteopathic Manipulative Medicine; OMT: Osteopathic Manipulative Treatment; OR: Odds Ratio; P: Probability; PIPP: Premature Infant Pain Profile; Q: Questionnaire; RC: Routine Care; RCT: Randomized Controlled Trial; SBS: Sphenobasilar Synchondrosis; SD: Somatic Dysfunction; SG: Study Group; SI: Sacroiliac; Sig: Significance; ST: Soft Tissue; Tx: Treatment.

\begin{tabular}{|c|c|c|c|}
\hline Author, Year & Objective & LOS Reduction & Cost Savings \\
\hline $\begin{array}{l}\text { Cerritelli., } \\
\text { et al. } 2013 \\
{[16]}\end{array}$ & $\begin{array}{c}\text { Investigate the effect of OMT on LOS in } \\
\text { premature infants }\end{array}$ & $\begin{array}{c}\text { LOS reduction of } 6 \text { days } \\
(-5.906 \text { days; } 95 \% \text { CI }-7.944 \text { to }-3.869 ; \mathrm{p}<0.001)\end{array}$ & $\begin{array}{c}€ 2,958.39(\$ 3,229.82) \text { per infant } \\
(95 \% \mathrm{CI}, € 1,983.77 \text { to } \\
€ 3,933.00 / \$ 2,165.78 \text { to } \$ 4293.85 \\
P=0.01)\end{array}$ \\
\hline $\begin{array}{l}\text { Pizzolorusso., } \\
\text { et al. } 2014^{17}\end{array}$ & $\begin{array}{l}\text { Assess if osteopathic care is } \\
\text { effective in reducing LOS and that } \\
\text { early OMT produces the most } \\
\text { pronounced benefit, compared to } \\
\text { moderately early and late OMT. }\end{array}$ & $\begin{array}{l}\text { LOS reduction of } 2 \text { days with late OMT }(<14 \mathrm{~d} \text { from birth }) \\
\qquad(-2.03 \text { days; } 95 \% \text { CI }-3.15 \text { to }-0.91 ; \mathrm{p}<0.01) \\
\text { LOS reduction of } 3 \text { days with moderately early OMT }(<9 \mathrm{~d}) \\
\quad(-3.12 \text { days; }-4.36 \text { to }-1.89 ; \mathrm{P}<0.001) \\
\text { LOS reduction of } 4 \text { days with early OMT }(<4 \mathrm{~d}) \\
\quad(-4.16 \text { days; }-6.05 \text { to }-2.27 ; \mathrm{p}<0.001)\end{array}$ & $\begin{array}{c}€ 740(\$ 812.19) \text { per infant } \\
(-€ 1309.54 \text { to }-€ 170.33 / \$ 1,437.29 \text { to } \\
\$ 185.96 ; \mathrm{P}=0.001)\end{array}$ \\
\hline $\begin{array}{l}\text { Ceritelli., et al. } \\
2015^{18}\end{array}$ & $\begin{array}{l}\text { Study the extent to which OMT is ef- } \\
\text { fective in reducing days of hospitaliza- } \\
\text { tion in a sample of premature infants } \\
\text { enrolled at } 3 \text { NICUs. }\end{array}$ & $\begin{array}{c}\text { LOS reduction of } 4 \text { days } \\
(-3.944 \text { days; } 95 \% \text { CI }-5.548 \text { to }-2.34 ; \mathrm{p}<0.001)\end{array}$ & $\begin{array}{c}€ 1,586.01(\$ 1,731.53) \text { per infant } \\
(95 \% \mathrm{CI}, € 1,087.18 \text { to } \\
€ 6,277.28 / \$ 1,186.93 \text { to } \$ 6,853.22)\end{array}$ \\
\hline
\end{tabular}

Table 2: Comparison of LOS and Cost savings among three RCTs. 


\section{Results}

The searches from PUBMED, SCOPUS, and EMBASE yielded a total of 59 results. 15 titles were selected for full text review and 5 were omitted because they were not full text manuscripts (two were poster presentations, one was an oral presentation, one was a protocol for an already published RCT included in this paper) or they were not performed as an osteopathic technique (one had physiotherapist perform manipulation). Of the 10 remaining titles, there was one case study, one prospective observational study, one retrospective review, five randomized controlled trials, one model proposal and one protocol. One study was based in the United States, eight were based out of Italy and one was based out of Austria.

In 2011, Lund and associates [10] published a case study using OMT on premature twins with a complex NICU course that improved their ability to nipple feed and prevented the need for gastrostomy tube placement. They provided soft tissue (ST), balanced ligamentous tension (BLT), myofascial release (MFR), inhibition, and cranial osteopathy daily for 3 weeks. This treatment approach demonstrated the positive effect of OMT for coordination of suck and swallow.

Pizzolorusso and associates [11] published a retrospective review of data in 2013 on the prevalence of somatic dysfunction and cranial strain patterns in 155 preterm and term newborns admitted to the NICU. They found that the highest prevalence of somatic dysfunction occurred in the pelvis and spine and the most frequent cranial somatic dysfunction were SBS compression and lateral/ vertical strain patterns. They did not treat these infants, they only collected diagnostic data.

A majority of the studies in this systematic review compared the use of OMT versus a control group to look at the effect on LOS and cost. The first was a prospective, non - randomized longitudinal cohort study conducted between January 2005 and June 2008 by Pizzolorusso and associates [12] , examining the effect of OMT on gastrointestinal function and LOS of preterm infants. Indirect MR, sutural spread, BLT, and balanced membranous tension (BMT) was performed on the infants 20 - 30 minutes twice per week. The authors indicated that preterm infants treated in the OMT group had a significantly reduced hospital LOS of at least 28 days $(p=.03$; adjusted $\mathrm{OR}=0.22 ; 0.09-0.51$ ) and reduced risk of GI symptoms by $55 \%$, such as vomiting, regurgitation, gastric reflux and enema administration (adjusted OR $=0.45 ; 0.26-0.74$ ).

Three different RCTs, Cerritelli and associates [13], Pizzolorusso and associates [14], and Cerritelli and associates [15] examined the effect of OMT on LOS in preterm infants at different time periods. These differences are indicated in Table 2. Cerritelli and associates [16]16 performed a single blinded RCT on 101 preterm newborns using OMT. The control group received only an osteopathic examination and then were not touched by the provider for the remainder of the session, whereas the experimental group received MFR, BLT, BMT, indirect fluidic technique and v - spread. Both groups received the intervention for 20 minutes twice per week. The results demonstrated a significant association between OMT and LOS reduction of 6 days in the treated group, but did not find that OMT was associated with any change in daily weight gain.

Pizzolorusso and associates [17] analyzed LOS and cost after performing OMT at different times after birth in 110 moderate and late preterm infants. An osteopathic examination then no touch was performed on the control group for 20 minutes twice per week. The treatment group received indirect MFR, BLT, and BMT 20 minutes twice per week but the treatment was performed at different time frames. The treatment group either received their first OMT session early ( $<4$ days from birth), moderately early ( $<9$ days from birth), or late ( $<14$ days from birth). The authors found that OMT is effective in reducing LOS and the sooner the treatment was received, the sooner the infants were discharged from the hospital. Those infants who received OMT early had the greatest reduction in LOS with 4 days (- 4.16 days; -6.05 to $-2.27 ; p<0.001)$, 3 day reduction with moderately early OMT (- 3.12 days; - 4.36 to -1.89 ; $\mathrm{P}<0.001)$, and 2 day reduction with late OMT (- 2.03 days; $95 \%$ CI -3.15 to $-0.91 ; \mathrm{p}<0.01$ ).

Cerritelli and associates [18] performed a RCT between NICUs at 3 different hospitals to investigate the effect of OMT on LOS, cost and daily weight gain. The control group received an osteopathic evaluation and then no touch for 30 minutes twice per week. The treatment group received MFR, BLT, and BMT for 30 minutes twice per week. The authors found a statistical difference in reduction of LOS of 4 days (- 3.944 days; $95 \%$ CI - 5.548 to - 2.34; $\mathrm{p}<0.001$ ) and cost saving of $\$ 1,731.53$ (95\% CI, $€ 1,087.18$ to $€ 6,277.28 / \$ 1,186.93$ to $\$ 6,853.22$ ) between the OMT treated group and control group. 
Martelli and associates [16] compared infants treated with osteopathic sham therapy to a control group who received only routine pediatric care to assess if preterm infants are affected by the placebo effect. The control group was not touched; the osteopath sat by the crib and watched quietly for 20 minutes twice a week. The sham group received an osteopathic evaluation and light touch through the entire musculoskeletal system for 20 minutes twice per week. They noted that there was no significant difference between the sham and control group for LOS $(30 \pm 20.3 ; 28.8 \pm 18.9$; $\mathrm{p}=0.70$ ), therefore they can infer that sham therapy does not have an effect on infants and can be used in subsequent studies. This study also demonstrated that compared to the above three RCTs [14-16], sham OMT is less effective on LOS compared to the real treatment $(-1.89 ;-6.45,2.66 ; \mathrm{p}=0.41)$.

All of the studies discussed thus far have shown a positive effect using OMT on LOS in preterm infants. There is one study, involving visceral OMT, which shows negative effects. Haiden and associates [17] performed OMT on 21 premature infants using an already established protocol for visceral treatment for adults to determine if it accelerates complete meconium excretion and improved feeding tolerance compared to a control group of 20. The OMT algorithm performed on the infants consisted of: abdominal fascial tension; lower rib and thoracic diaphragm release; pylorusre lacation; duodenum and C - loop release; small intestine diagnosis - lifting the gut and bringing it to a stillpoint; mobilization of the ileocoecal valve, mobilization of colon ascendens, transversum, descendens with treatment of the Toldt fascia; root of sigmoid diagnosis and manipulation; craniosacral therapy to treat vagus nerve. Compared to the control group, the intervention group took 1.5 days longer to reach complete meconium excretion ( 6 vs 7.5; $p=-0.11$ ), was associated with an 8 day longer time to full enteral feedings (median 34 days, 95\% CI; 30 - 48; $\mathrm{p}=0.02$ ) and 35 day longer hospital stay (median 66 days; $\mathrm{p}=0.14$ ).

Cerritelli and associates [18] realized that there was no standardization for OMT performed on infants in the NICU. In 2014, a protocol for standardization of the osteopathic approach to treating hospitalized newborns (NE - 0 model*) was published and was developed to maximize the effectiveness and clinical use of OMT in the NICU. This publication had no between group comparisons or data results. There are two phases of the NE - O model, one is evaluation and the other is treatment. The evaluation procedure consisted of the following: first assessing the skull for cranial strain patterns, condylar compression and suture or fontanelle abnormalities, next assessing the spine, pelvis, upper limbs, lower limbs, rib cage, diaphragm and finally the viscera. The treatment included indirect techniques, such as counterstrain, cranial, facilitated positional release, functional, and balanced ligamentous tension.

One final article that is included in this review is a study protocol written by Cerritelli and associates [19] that sets the stage for a randomized controlled trial to examine the use of OMT in reducing pain in preterm infants. In this study they will randomize infants into a study group, sham group, and control group and analyze the differences based on a premature infant pain profile (PIPP) questionnaire, length of stay and cost between each group. The PIPP questionnaire is a seven - item multidimensional measure of pain. The results of this study have not yet been published.

\section{Discussion}

The present systematic review found a variety of studies and the aim of this paper was to summarize the evidence of using osteopathic medicine as diagnosis and to evaluate the effectiveness of OMT as an adjunct treatment option for infants in the NICU. Ten articles were found addressing the use of OMT in the NICU, six studies favored OMT and showed a positive effect [10,12-16], one showed a negative effect [17], two did not report any between group comparisons [11,18], and the remaining one describes a study protocol and the study results have not yet been published [19].

Overall, results suggest a potential effect of osteopathic medicine in medical conditions associated with infants in the NICU and conditions that are related to prematurity. One of the categories to allow the newborn to leave the NICU is adequate oral feeding. 6 Lund and associates [10] were able to present a case study where OMT was used on premature twins, improving their ability to nipple feed and prevented the need for gastrostomy tube placement, therefore accelerating their departure from the NICU. Pizzolorusso and associates [14] presented a retrospective review of diagnostic data, proving that there is a large prevalence of somatic dysfunc-

\footnotetext{
${ }^{1 \text { "NE}} \mathrm{O}$ model" was described, but no further elaboration of the term is found in the medical literature.
} 
tion and cranial strain patterns in newborns in the NICU. A cohort study was performed by Pizzolorusso and associates [15] who found a positive effect of OMT on reducing GI symptoms and reducing LOS of preterm infants in the NICU. Three RCTs performed by Cerritelli and associates [16], Pizzolorusso and associates [17], and Cerritelli and associates [18] were consistent with each other in regards to LOS and cost reduction. In 2013, Cerritelli and associates [16] reported the largest benefit of OMT on LOS with a reduction of almost 6 days. Pizzolorusso and associates [17] and Cerritelli and associates [18] demonstrated a smaller decrease of LOS of 4 days comparatively, although both are still significant. The difference among these three studies may be due to population of infants studied. Martelli and associates [16] conducted a study to compare infants treated with osteopathic sham therapy to a control group with no exam or treatment and demonstrated that there was no significant difference between the sham and control group, therefore sham therapy can be used in later studies. Only one study, performed by Haiden and associates [17], reported longer time to full enteral feedings, longer time to reach complete meconium excretion and increased LOS when using visceral OMT techniques on infants in the NICU. In 2014, Cerritelli and associates [18] published the NE - 0 model which is a protocol for standardization of the osteopathic approach to treating hospitalized newborns in the NICU. This standardization consists of both evaluation and treatment; it does not provide any between group comparisons or data results. The final article included in this review is a study protocol written by Cerritelli and associates19 that will be a RCT examining the use of OMT in reducing pain in preterm infants.

The main limitations in all of these studies were sample size and using infants from only one NICU, which may not be representative of the greater preterm infant population. The cost estimation was based on a theoretical approach for most of the studies, rather than the real hospital stay for each patient. The subjects were often preterm clinically stable infants with no other complications. A detailed list of limitations for each study is shown in table 3.

All of these studies allowed manipulative treatment to be individualized by the osteopath treating each infant, without standardized treatment protocols. Better quality results may be attained if the NE - O model [18] is used for future studies.

\begin{tabular}{|l|l|l|l|}
\hline \multicolumn{1}{|c|}{ Author, Year } & \multicolumn{1}{|c|}{ Study Design } & \multicolumn{1}{|c|}{ Objective } & \multicolumn{1}{c|}{ Limitations } \\
\hline Lund., et al., 2011 [10] & Case Study & $\begin{array}{l}\text { Add to the interest and support } \\
\text { for a clinical trial of OMT and } \\
\text { its effect on poor nipple feed- } \\
\text { ing in developing premature } \\
\text { newborns and infants }\end{array}$ & $\begin{array}{l}\text { It is a case study, no between group compari- } \\
\text { sons }\end{array}$ \\
\hline $\begin{array}{l}\text { Pizzolorusso., et al., } 2011 \\
{[12]}\end{array}$ & $\begin{array}{l}\text { Prospective Cohort } \\
\text { Study }\end{array}$ & $\begin{array}{l}\text { Effect of OMT on GI function } \\
\text { and LOS of preterm infants }\end{array}$ & $\begin{array}{l}\text { Only one NICU - population not representa- } \\
\text { tive } \\
\text { Unable to include confounding variables such } \\
\text { as maternal/delivery factors, respiratory sup- } \\
\text { port, method of feeding \& gastric emptying } \\
\text { time. } \\
\text { Treatment allocation was not randomized or } \\
\text { structured. }\end{array}$ \\
\hline $\begin{array}{l}\text { Not possible to "blind" nurses and neonatolo- } \\
\text { gists to treatment regimen. }\end{array}$ \\
$\begin{array}{l}\text { Did not discriminate between preterm \& term } \\
\text { neonates. }\end{array}$ \\
\hline
\end{tabular}




\begin{tabular}{|c|c|c|c|}
\hline $\begin{array}{l}\text { Pizzolorusso., et al., } 2013 \\
\text { [11] }\end{array}$ & $\begin{array}{l}\text { Retrospective Re- } \\
\text { view }\end{array}$ & $\begin{array}{l}\text { Determine prevalence of SD } \\
\text { and cranial strain pattern in } \\
\text { newborns at the first osteo- } \\
\text { pathic structural exam. }\end{array}$ & $\begin{array}{l}\text { Limited sample size - no subgroup analysis. } \\
\text { Grades of severity for SD and cranial strain } \\
\text { pattern not reported. } \\
\text { Lack of data of study population - no further } \\
\text { association with clinical symptoms. } \\
\text { No data regarding route of delivery. }\end{array}$ \\
\hline Cerritelli., et al., 2013 [13] & RCT & $\begin{array}{l}\text { Investigate the effect of OMT on } \\
\text { LOS in premature infants }\end{array}$ & $\begin{array}{l}\text { Small sample size. } \\
\text { Only } 1 \text { NICU - not representative of preterm } \\
\text { infant population. } \\
\text { Maternal socioeconomic status not collected - } \\
\text { potential cofounder. } \\
\text { Hospital relocation was mostly from study } \\
\text { group - could be AE from OMT, type of popula- } \\
\text { tion, small sample size and fragile newborns' } \\
\text { condition } \\
\text { Cost evaluation based on theoretical approach } \\
\text { and not the actual cost }\end{array}$ \\
\hline $\begin{array}{l}\text { Pizzolorusso., et al., } 2014 \\
\text { [14] }\end{array}$ & RCT & $\begin{array}{l}\text { Assess if osteopathic care is ef- } \\
\text { fective in reducing LOS and that } \\
\text { early OMT produces the most } \\
\text { pronounced benefit, compared } \\
\text { to moderately early and late } \\
\text { OMT } \\
\text { Estimate hospital cost savings } \\
\text { by using OMT }\end{array}$ & $\begin{array}{l}\text { Only one NICU. } \\
\text { Cost estimates were based on a theoretical ap- } \\
\text { proach, not the real hospital stay. }\end{array}$ \\
\hline Martelli., et al., 2014 [16] & RCT & $\begin{array}{l}\text { To assess the presence of pla- } \\
\text { cebo effect in newborns using } \\
\text { sham OMT }\end{array}$ & $\begin{array}{l}\text { Small sample size } \\
\text { Only one single NICU - not representative of } \\
\text { the general preterm infant population } \\
\text { Sham therapy was not directly compared to } \\
\text { OMT } \\
\text { Cannot tell if sham therapy is effective in im- } \\
\text { proving subjective outcomes }\end{array}$ \\
\hline Cerritelli., et al., 2014 [18] & Model & $\begin{array}{l}\text { Suggest a protocol on osteo- } \\
\text { pathic approach (NE-O model) } \\
\text { in treating hospitalized new- } \\
\text { borns. Model was developed to } \\
\text { maximize the effectiveness and } \\
\text { clinical use of osteopathy into } \\
\text { NICU }\end{array}$ & $\begin{array}{l}\text { Cannot be compared to pre-existing methods } \\
\text { - due to lack of standardized osteopathic pro- } \\
\text { cedures in neonatology. }\end{array}$ \\
\hline
\end{tabular}




\begin{tabular}{|c|c|c|c|}
\hline Cerritelli., et al., 2015 [15] & RCT & $\begin{array}{l}\text { Study the extent to which OMT } \\
\text { is effective in reducing days of } \\
\text { hospitalization in sample of } \\
\text { premature infants enrolled at } \\
3 \text { NICUs. Also explore whether } \\
\text { OMT is effective in reducing } \\
\text { costs and daily weight gain }\end{array}$ & $\begin{array}{l}\text { Sample selected was mainly preterm clinically } \\
\text { stable infants. } \\
\text { NICU costs came from standardized reim- } \\
\text { bursement form. } \\
\text { Few number of protocol variations. } \\
\begin{array}{l}\text { Day of discharge may be influenced by day of } \\
\text { week, neonatologist and NICU }\end{array}\end{array}$ \\
\hline Haiden., et al., 2015 [17] & $\mathrm{RCT}$ & $\begin{array}{l}\text { Determine if visceral OMT ac- } \\
\text { celerates complete meconium } \\
\text { excretion and improved feed- } \\
\text { ing tolerance in very low birth } \\
\text { weight infants }\end{array}$ & $\begin{array}{l}\text { Informed consent could not be achieved in } \\
\text { time (OMT had to be applied during } 1 \text { st } 48 \\
\text { hour of life) for some cases. } \\
\text { Small sample size prevented detection of } \\
\text { more significant effect size. }\end{array}$ \\
\hline Cerritelli., et al., 2015 [19] & RCT Protocol & $\begin{array}{l}\text { Explore the effectiveness of } \\
\text { OMT in reducing pain in a sam- } \\
\text { ple of preterms }\end{array}$ & $\mathrm{N} / \mathrm{A}$ \\
\hline
\end{tabular}

Table 3: List of limitations of each study.

\section{Conclusion}

This systematic review suggests that osteopathic treatment may be beneficial in reducing many clinical manifestations that occur in infants in the NICU and can also reduce LOS and cost for an infant in the NICU.

More randomized controlled trials with a standardized treatment protocol, such as the NE - O model, or the comparison of sham therapy vs OMT are needed to confirm the results found in the discussed studies and generalize them to a broader population of high risk newborns.

Possible direction for future studies is to evaluate if there is an age or birth weight at which OMT is unsafe for the preterm newborn. Another question that could be asked and followed through the life of the children who have received OMT, is if doing manipulation in preterm infants can change the possibility of developmental delays and physical delays that can become a problem later in the life of these children.

\section{Conflicts of Interest}

The authors have no conflicts of interest. The authors are not employed by, nor receiving funding or stock, nor in ownership of funding or stock from any source for the research within or for the publication of this paper.

\section{Bibliography}

1. Blencowe H, Cousens S, Oestergaard MZ, Chou D, Moller AB, Narwal R, Adler A, Garcia CV, Rohde S, Say L, Lawn JE. National, Regional, and Worldwide Estimates of Preterm Birth Rates in the Year 2010 with Time Trends since 1990 for Selected Countries: A Systematic Analysis and Implications. The Lancet. 2012; 379: 2162-72.

2. Hamilton BE, Martin JA, Osterman MJK, Curin SC, Mathews TJ. Births: Final Data for 2014. National Vital Statistics Reports. 2015; 64 (12): 1-64.

3. WHO March of Dimes, PMNCH. In: Howson CP, Kinney MV, Lawn JE, editors. Save the Children: Born too Soon: The Global Action Report on Preterm Birth. Geneva: World Health Organization; 2012

4. Institute of Medicine (US) Committee on Understanding Premature Birth and Assuring Healthy Outcomes; Behrman RE, Butler AS, editors. Preterm Birth: Causes, Consequences, and Prevention. Washington (DC): National Academies Press (US); 2007. 12, Societal Costs of Preterm Birth. Available from: http://www.ncbi.nlm.nih.gov/books/NBK11358/ 
5. March of Dimes. Premature Birth: The Financial Impact on Business. Truven Health Analytics, Inc. 2013. Accessed 12/24/15 at http://www.marchofdimes.org/materials/premature-birth-the-financial-impact-on-business.pdf

6. Backewell-Sachs S, Medoff-Cooper B, Escobar GJ, Silber JH, Lorch SA. Infant Functional Status: The Timing of Physiologic Maturation of Premature Infants. Pediatrics. 2009. 123: 878886

7. Carreiro, Jane E. "Chapter 14." An Osteopathic Approach to Children. 2nd ed. Edinburgh: Churchill Livingstone/Elsevier, 2009. 225-29. Print.

8. Guiney, Peter A., DO, Rick Chou, DO, Andrea Vianna, MD, and Jay Lovenheim, DO. "Effects of Osteopathic Manipulative Treatment on Pediatric Patients With Asthma: A Randomized Controlled Trial." JAOA 105 (2005): 7-12.

9. Posadzki P, Lee MS, Ernst E. Osteopathic Manipulative Treatment for Pediatric Conditions: A Systematic Review. Pediatrics. 2013; 132: 140-152

10. Lund GC, Edwards G, Medlin B, Keller D, Beck B, Carreiro JE. Osteopathic manipulative treatment for the treatment of hospitalized premature infants with nipple feeding dysfunction. J Am Osteopath Assoc. 2011 Jan; 111(1): 44-8.

11. Pizzolorusso G, Ceritelli F, D’Orazio M, Cozzolino V, Turi P, Renzetti C, Barlafante G, D'Incecco C. Osteopathic evaluation of somatic dysfunction and craniosacral strain pattern among preterm and term newborns. J Am Osteopath Assoc. 2013 Jun; 113(6): 462-7.

12. Pizzolorusso G, Turi P, Barlafante G, Cerritelli F, Renzetti C, Cozzolino V, D’Orazio M, Fusilli P, Carinci F, D'Incecco C. Effect of osteopathic manipulative treatment on gastrointestinal function and length of stay of preterm infants: an exploratory study. Chiropr Man Therap. 2011 Jun 28; 19(1): 15.

13. Cerritelli F, Pizzolorusso G, Ciardelli F, La Mola E, Cozzolino V, Renzetti C, D'Incecco C, Fusilli P, Sabatino G, Barlafante G.Effect of osteopathic manipulative treatment on length of stay in a population of preterm infants: a randomized controlled trial.BMC Pediatr. 2013 Apr 26;13:65.
14. Pizzolorusso G, Cerritelli F, Accorsi A, Lucci C, Tubaldi L, Lancellotti J, Barlafante G, Renzetti C, D'Incecco C, Perri FP. The Effect of Optimally Timed Osteopathic Manipulative Treatment on Length of Hospital Stay in Moderate and Late Preterm Infants: Results from a RCT. Evid Based Complement Alternat Med. 2014;2014:243539

15. Cerritelli F, Pizzolorusso G, Renzetti C, Cozzolino V, D’Orazio M, Lupacchini M, Marinelli B, Accorsi A, Lucci C, Lancellotti J, et al. A multicenter, randomized, controlled trial of osteopathic manipulative treatment on preterms. PLoS One. 2015 May 14; 10(5): e0127370. Doi: 10.1371/journal.pone.0127370

16. Martelli M, Cardinali L, Barlafante G, Pizzolorusso G, Renzetti C, Cerritelli F. Do placebo effects associated with sham osteopathic procedure occur in newborns? Results of a randomized controlled trial. Complement Ther Med. 2014 Apr;22(2):197202.

17. Haiden N, Pimpel B, Kreissl A, Jilma B, Berger A. Does visceral osteopathic treatment accelerate meconium passage in very low birth weight infants?- A prospective randomized controlled trial. PLoS ONE 2015;10(4): e0123530. Doi: 10.1371/ journal.pone.0123530

18. Cerritelli F, Martelli M, Renzetti C, Pizzolorusso G, Cozzolino V, Barlafante G. Introducing an osteopathic approach into neonatology ward: the NE-O model. Chiropr Man Therap. 2014 May 9; 22:18

19. Cerritelli F, Cicchitti L, Martelli M, barlafante G, Renzetti C, Pizzolorusso G, Lupacchini M, D’Orazio M, Marinelli B, Cozzolino V, Fusilli P, D'Incecco C. Osteopathic manipulative treatment and pain in preterms: study protocol for a randomized controlled trial. Trials. 2015; 16(1)

\section{Volume 3 Issue 10 October 2019 (C) All rights are reserved by Hunter J Wernick and Murray R Berkowitz.}

